УДК 94 (439.23)-Druget«16/17»

DOI: $10.24144 / 2523-4498.2(43) .2020 .217367$

\title{
HISTORICAL PERSONALITY AND CONTRIBUTION OF GEORGE III DRUGET IN ZEMPLÉN AND UNG COUNTIES AT THE TURN OF THE 16TH AND 17TH CENTURIES
}

\author{
prof. ThDr. PhDr. Lenčiš Štefan PhD \\ Director of the Institute of Church History at Catholic University in Ruzomberok, Košice, Slovakia \\ E-mail: stefan.lencis@ku.sk
}

\begin{abstract}
Among the many important aristocratic families, the Druget family from Homonna (Humenné), who are among the most influential aristocratic families in Hungary, is an important historical activity. For more than three and a half centuries of operation, the famous Druget family in Hungary created rich historical events. A well-known historian, Matej Bel, wrote at the beginning of the 18th century, looking at the Humensky manor house: "It is the ancient seat of this family, and the castle was so adorned that it was barely the same far and wide ...». Matej Bel's wish had not been fulfilled yet. Neither the Drugetians themselves nor their descendants were interested in revealing their ancient and rich family history for future generations. Through the life of George (György) III Druget (Drugeth), we want to point out that a member of this vital family is at least to a small extent. This year, we commemorate 400 years since the death of Count George III, who at the turn of the 16th and 17th centuries made a significant contribution to the history of the Zemplén and Ung counties. His life was mostly connected with the towns of Homonna (Humenné) and Ungvár (Uzhhorod). George III belonged to one of Hungary's most important family members in the political, economic, cultural, and religious fields. The study of archival sources brings new knowledge. With this work, we want to fill a gap in historical research at least partially. We want to specify the historical events of the most important events associated with George III Drugeth and topics: missionary activity of the Jesuits, the establishment of the college in Homonna (Humenné), and its transfer to Uzhhorod and Uzhhorod Union. At the same time, operating in those fields represents their mutual influence, cooperation, achievement, and difficulties. We want to point out their essential position in decisive historical moments. The work also seeks to refute today's people's often-one-sided attitude towards noble families, who, due to the recent communist past's influence, are still perceived as exploiters and mighty noblemen.
\end{abstract}

Keywords: Drugeth, castle, count, grammar school, properties, county.

The aim of this paper - on the occasion of 400 years since the death of count George III Druget - is more detailed to present one of the most important figures of this aristocratic family at the turn of the 16th and 17th centuries. This historical figure is significantly recorded in the history of the Zemplén and Ung counties. The paper aims to offer new knowledge in the activity of the researched personality in the cultural and religious field (missionary activity of the Jesuits, the establishment of a college in Humenné and later in Uzhhorod, Uzhhorod Union). The paper, which is based on primary foreign and domestic literature (Borbély, Z., Dongó, G. Gy., Bagin, A., Machala, J., Lacko, M., Szirmay, A., Mészáros, K., Krapka, E. - Mikula, V., Stolárik, S., Lenčiš, Š.), Also enrich new archival sources (Archivum Secr. Vaticanum, ARSI Austria and the State Archive in Prešov).

Count George (György) III Druget, from the famous Druget family, also took an important historical place. He headed Zemplén and Ung counties at the turn of the 16th and 17th centuries, which significantly influenced the historical events in this area. [See: Lenčiš, 2003]. George III Druget was born in 1583 to his father George II and to the mother Euphrozina, née Dóczy. Catherine Nádasdy was married, and they had two children together: Elisabeth and John IX. He died on June 21, 1620. He spent most of his time in Uzhhorod, which he had obtained as a heritage. In the Druget family, the way of inheriting was that the family did not inherit or own property in parts. However, in such a way that family members received their share wherever they had property. We can often see George as a young man next to his cousin Valentine (Bálint) I. He was a member of the national party, where he was also actively involved. In 1599 (April 1), king Rudolf promoted him to the office of mayor of Ung county. He acquired this office after the death of the former mayor Stephen V. Druget [ŠA Prešov, Drugeth - Humenné, inv. no. 80a, sign. I 80a].

In 1600 , at the age of seventeen, he was sentenced to the loss of his castle in Terebes (Trebišov) and its belongings and death. The reason was the claim that he had committed great violence in six counties against the nobles, especially Peter Zokoly and Simon Bánóci. However, the reality was different. The mentioned nobles Peter Zokoly and Simon Bánóci conceived a great deception against George III the Druget by which they wanted to seize those properties for themselves. They bribed the old maid of countess Eufrozine Dóczy, the widow of George II Druget. The maid had run away from her lady to countess Eufrozine Török, widow of Stephen $\mathrm{V}$ Druget, and, under oath not to send her back to her lady, revealed her secret. According to it, George III Druget is not the real son of his parents. Allegedly, when George III was a small child, he fell out of his maid's hands while playing and died. Desperate, the mother closed herself into the room and declared that the child was ill. Then, she left and brought a child from a nearby village to make everything look the same. Afterward, she secretly buried her child. When countess Euphrózina Török found out, she told her son Valentine I. The count realized that if that were true, all the property of George 
III would belong to him. He took advantage of the situation and, with 3,000 soldiers, attacked Nevicke castle on the Uzhhorod estate around the feast of All Saints (November 1). Countess Euphrozine Dóczy was at the castle together with her children: George III. and daughter Mária [Borbély, Homonnai Drugeth, 2017, old. 297]. Valentine failed to get to the castle due to strong resistance, so he forced the castle gates to open by stopping water flow to the castle. Eventually, the countess had to give up and managed to escape under challenging conditions with the children to Poland. The military raid on the castle took place at the time when one royal army was in Transylvania, and the other was fighting against the Turks. Count Valentine I outraged the king with this situation, which was also expressed in his accusation: «Against the public order of the Kingdom of Hungary and the Holy Crown, he was not boldly afraid to stand ...». Subsequently, king Rudolf summoned Valentine and his companion to Pressburg (Bratislava) in 1602. He fell to the displeasure of the king and should have come to justify it. Archduke Matthew, who was the king's brother and other nobles, defended Valentine before the king. The king forgave him, as the charter testifies: "When we look with the eyes of kindness and our kindness of imperial and royal at Valentine Homonna (Humenné), and when we see his good qualities and faithful services which he demonstrated, and after he aroused displeasure in himself, it put it aside for the sake of his transgression and subsequent law. The resulting reputation of eternal faithfulness, we have done, by our imperial grace, to be exempt from legal action of any punishment on our part, or of the royal fiscal against it for a given reason» $[\mathrm{MNL}-\mathrm{A} 57, \mathrm{MKL}$, LR, zv. 5, s. 580-582].

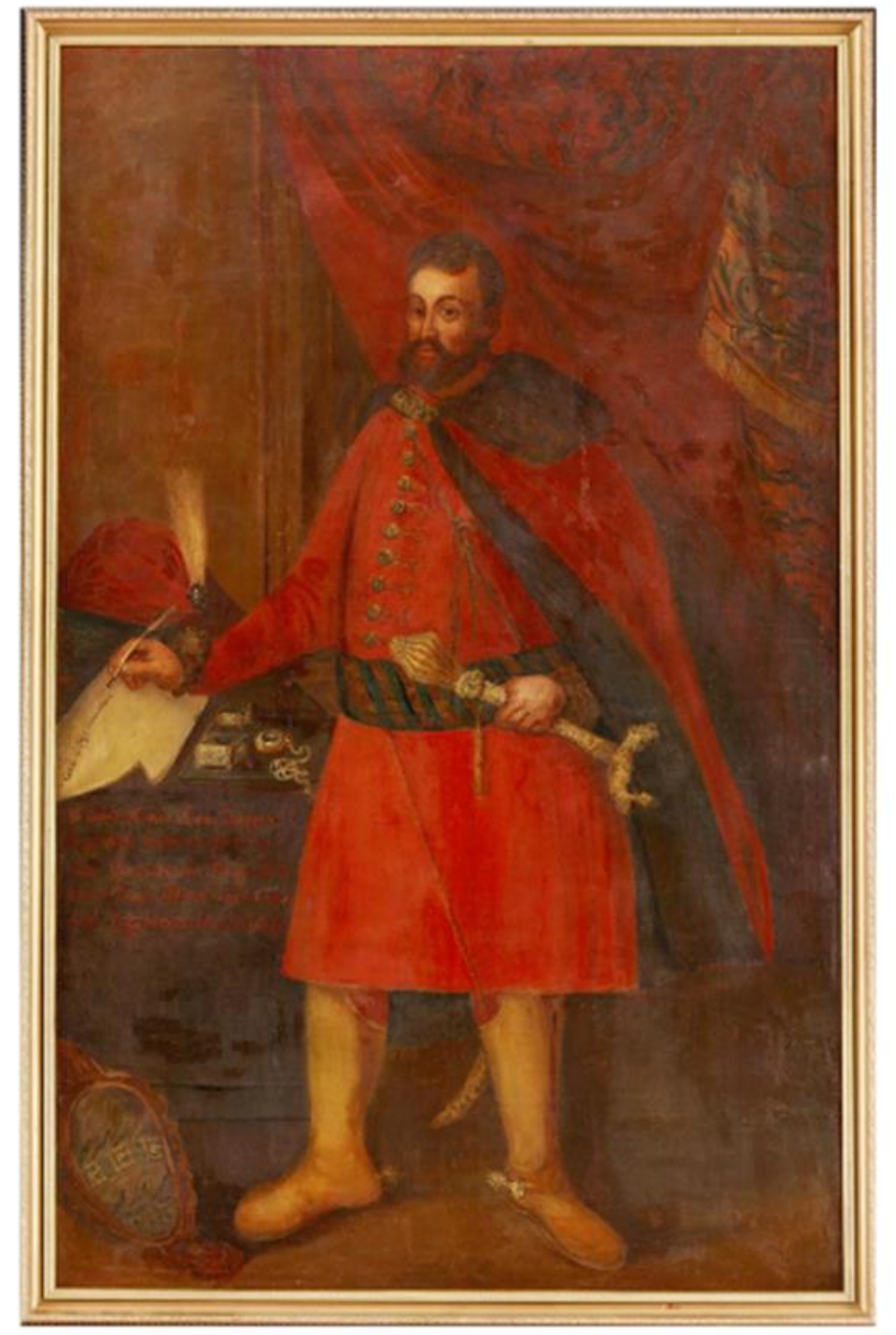

George III Druget

Peter Zokoly, the main initiator of that unfair plan, made sure that even Valentine I, who was lured into a trap, no longer stood in his way. Now, an empty road appeared to him. The court cases had been prolonged too much, as the whole case seemed quite untrue. In the end, however, a verdict was handed down: George III was sentenced to be beheaded and to lose his property. The damage caused to Zokoly was assessed at HUF 25 000, and in addition to this amount, it was to account for a third of the seized property as a claimant. He was to receive the Terebes (Trebišov) estate from the Druget estate. This decision provoked anger with his partner 
Simon Bánoci. He found out that the Falcons had deceived him [ŠA Prešov DH inv. c. 503. 1. Fasc. 4. №. 10]. He wrote a letter to King Rudolf, to which he also attached a treaty, which they both had signed before that whole situation. In the letter, he objected that the judges awarded Zokoly twenty-five thousand forints as court costs, but his actual costs were barely 30 forints. Count of Humenné's people did not attack Zokoly, but him; his wife was beaten, and yet everything went to Zokoly, since according to the contract concluded in advance, half of the profit should belong to him. Meanwhile, the chamber sought to find a suitable buyer for the confiscated property. After many delays and unsightly calculations, the Bratislava Chamber itself took the monarch's initiative to pardon Druget. «If itis agreed well with him», the chamber wrote in a letter dated March 26, 1602, to king Rudolf, «more benefit can be expected from him (from Druget) than from Zokoly, who defeats poverty and deprives the wealthy of all their possessions and brings the poor to their heads》.

At the same time, archduke Matthias spoke with the chamber in favor of George III Druget and warmly recommended him as a brave and trustworthy young man. Because Druget was willing to exchange his possessions for money, the king allowed the «civilly dead» earl to come home for six months in the same year and organize his affairs. Before his journey to his dominion, the count wrote a letter to the king. In it, he described with open sincerity and touchingly the injustices that had happened to him, his mother, and his sister. He also wrote in the letter: «I was 16 years old when our enemies accused us. I didn't know anything; I didn't take part in anything, and I never harmed anyone. And yet, the laws of the homeland condemned me to the loss of my head and property. The plaintiffs longing for my property, although they robbed and plundered my mother's property over the years, were richly rewarded». Finally, he asked the monarch to cancel the sentence and return the property to him.

Subsequently, the king commissioned the chamber to put all things in order with count George. Meanwhile, Druget returned home and personally came to the king. He won the monarch's favor, who granted him mercy and ordered so that his confiscated property was returned to him under certain conditions [Takács, old. 158-160]. One of the conditions was that his castle of Terebes (Trebišov) with all the facilities would be forwarded to the Royal Chamber [Mazúr, 1973, s. 207]. In 1602, he actually handed over this property to the royal chamber. At the National Assembly meetings in Korpona (Krupina) in November 1605, complaints were made that the property of George III had been mistreated [Réz, 1899, old. 87]. We do not know how that whole thing was handled, but in 1608, his innocence was declared. In 1613 , his property was returned to him, as stated in Article 41: «George Druget was found innocent and it is not right to deprive him of his property» [Szirmay, Notitia historica, old. 240].

Together with his cousin Valentine I and Stephen Ilésházy, he also took part in the negotiations that preceded Vienna's peace. He gained that trust from Bocskay. At that time, his work was not significant for two reasons. The first was that the older and more experienced Valentine, I was in the foreground, and the second reason was that he was still young [Réz, 1899, old. 87].

In 1608 , on November 19 , he took part in the coronation of king Matthew II. (1608 - 1619). He was the first of the family to convert to the Catholic faith. According to Michal Lacko, his conversion took place as early as 1605 . At that time, he was studying in Prague, where he became a Catholic under the influence of the Jesuits and the influence of the later Esztergom Cardinal Peter Pázmány [Lacko, 1957, s. 50].

From 1610 we have a record that a new county governor, George III, was appointed supreme administrator for the Zemplén chair. Druget from Homonna, who had previously been the Ung county mayor [Somogyi, 1902, old. 243], a knight with golden headlands, a master of Hungary's royal cuppers, a royal adviser, and butler. From the preserved decree issued by king Matthew II, we learn that he received this rank for special trust, loyalty, dexterity, and reliable control of public affairs [MNL - A 57, MKL, LR, zv. 14., s. 308]. However, he could not immediately perform the new position because the county's inhabitants rejected that appointment, stating that according to the law, this promotion was to be given to the son of Valentine I Stephen VI. Stephen VI was a Calvinist and, by law, was to be a hereditary robe, but at the time, he was still a child. King Matthew II justified his decision by saying that he could not entrust such a demanding and challenging office to a minor boy and that he had made this decision reluctantly. The reason was different. The inhabitants of the Zemplén county, who were for the most of the Calvinist faith, feared that George III as a zealous catholic, even against the will of the king, could become very involved in the re-Catholicization of the county. Documents can evidence the refusal of the county against George III. In one letter, the king himself indignantly disapproves of such an attitude and seriously demands George III to be accepted as a supreme mayor of the county. Palatine George Turzo joined the king's side with his admonition, even though he was of Lutheran faith. George III wrote a very courtesy letter about his unpleasant situation. to the sub-mayor of the county. In the end, he added that he was focusing his willingness for the needs of individual inhabitants. The whole problem was finally solved by the sudden death of Stephen VI. (suspicion of poisoning) on March 16, 1612. Interestingly, three days before the death of Stephen VI, his uncle George III had visited him. George III could, therefore, peacefully take over his office. Right at the beginning of his administration, he managed to return the Pauline order's property, who began to return from abroad. They were in Sátoraljaújhely, Olasz, Zsadány, and Sári. The county had administered these estates for several years because the monks fled in fear during Bocskay's uprising [Szirmay, Notitia historica,old. 139140].

When Bocskay's uprising broke out, the Jesuits were expelled from Transylvania in 1606. On their way to Poland, they passed through eastern Slovakia and found no catholic church from the Transylvanian town of Monostor to Homonna. On their way, they stopped in Humenné, where they were warmly received by count 
George III Druget and stayed there for eight days. At that time, count Druget already had two catholic priests with him [Lacko, 1957, s. 53-54].

The young count was zealous for his faith, as evidenced by the fact that on March 10, 1606, Pope Paul $\mathrm{V}$, being concerned about the situation in Hungary, sent several letters to important personalities, including George III, encouraging him to eagerly defend interests of Catholics during the upcoming session in Bratislava [Archivum Secr. Vaticanum, vol. 1. Fol. 248v. et alia copia etiam in vol. 1. A., fol. 451r]. In 1613, he managed to restore the old Pauline monastery in Sátoraljaújhely. The monks scattered from that monastery to various places during Bocskay's uprising.

In 1614, Druget received a golden crown (aureum vellus) from Pope Paul V (1605 - 1621) [Franzen, 1992, s. 333] and the emperor included him among the knights of the Order of the Golden Fleece [Réz, 1899, old. 90].

When the escaping Jesuits from Transylvania stopped in Homonna in 1606, there was father Johannes Argentus among them, who was the head of the Transylvania mission. The count used that opportunity to begin negotiations so that the Jesuits settled down in his city. As the count was interested in the pastoral work of the Jesuits at the Makovice estate and was enthusiastic about them, he also asked Pál Rákóczi to send such missionaries to his estate. Based on that request, in 1608, the provincial of the order sent him father Alfonz Carillo with two priests - John Sentdördi as a court chaplain and for the Slovaks in Homonna and its surroundings and the priest Michal Beška. Initially, they were both accommodated in a county mansion, and later they have donated a Franciscan monastery and a church, who had had to leave the city before the Reformation.

In 1609, father Alexander Dobokai came to Homonna and became the superior of this mission. The archival records from 1612 bring us reports that in the three years of the Jesuits' work in and around Homonna, up to 700 people left the Calvinist faith, and all the townspeople in the town themselves returned to the catholic faith. In 1614, the Jesuits ruled five parishes and, in 1615 , took over another six. There was only one Catholic priest in these eleven parishes, and he was very old [ARSJ, Austria, vol. 133, fol. 189]. The preserved report does not state which parish was involved. According to the time of the establishment of individual parishes, it is possible to determine with some probability which catholic parishes in the territory of the Humenský estate. It was Homonna, where there were two churches at the time - the parish church of All Saints in the square, where the Jesuits preached in Slovak, and the former Franciscan church, in which the Jesuits preached in Hungarian. Other parishes were in the villages of Czirokahosszúmezö (Dlhé nad Cirochou), Udwa (Udavské), Felsőkörtvélyes (Vyšný Hrušov), Papháza (Papín), Szerelmes (Lubiša), Laborcmező (Zbudské Dlhé), Jánosvölgye (Jankovce), Göröginye (Ohradzany), Barkó (Brekov), Örmező (Strážske) [Jurovský, 1976, s. 13]. In 1617, the Jesuits administered nine parishes, which formed 36 villages of the Homonna estate. Simultaneously, all these communities had already converted to the catholic faith [Lacko, 1957, s. 54]. In 1634, John Druget asked the bishop of Eger, Imre Lósi, who had his residence in Jasov, for jurisdiction for the Jesuits to work on a mission in the broader vicinity of Homonna [Székely, 1977, old. 12].

The Jesuits worked not only in Homonna and its surroundings. However, gradually by returning the other nobles to the catholic church, they wanted to have in their court, at least for the time being, one or two Jesuits. The Jesuits left Homonna for a mission, e.g. to Makovica to count Paul Rákóczi from 1612, to Ungvár to the Druget estate from the year 1613, to Kassa (Košice) to the imperial general from 1615, to Munkács to count Miklós Esterházi, to Pácin to count Melchior Alaghy, to Parnó (Parchovany) to countess Barbora Rákóczi from the year 1616, to Szepesvár (Spiš Castle) to Countess Erdődy from 1623, to Eperjes (Prešov) from 1624, to Varannó (Vranov) from 1615 and to Hanusfalva (Hanušovce) from 1637 [Székely, 1977, old. 12].

George III Druget, having been influenced by the missionaries' successful work, Druget also began to consider founding a college. Therefore, in a letter to the General Superior, father Claudio Aquaviva [Borbély, 2015, old. 180], who was in Rome, wrote in 1612 to establish a college in Homonna. The real interest of count George Druget in founding the Jesuit College in Homonna is also evidenced by a letter he had sent to Alexander Dobokai on July 9, 1613. The letter states, among other things: «I repaired the parish and the school nicely. I also provided you with pensions, only for God to bring you as soon as possible. You yourself should grasp the matter with both hands». After all the necessary preparations, the Jesuits came to Homonna on November 23 of the same year (1613) [Stolárik, 1995, s. 22-24].

Thus, a community was created, which had been grown to 15 members in 1614 . The Jesuits immediately founded a school in which they had a lower and upper grammar class. At that time, however, this community is neither listed as a residence nor a collegium. Its legal existence had not yet been established by the general of the order [Stolárik, 1995, s. 23].

In 1615, the General Superior of the Order, Father Claudius Aquaviva, approved the establishment of a residence and grammar school in Humenné [MNL - Acta Jesuitica. fasc. 14, num. 6]. Subsequently, on July 2 of the same year, George III Druget issued a founding charter of Ungvar's collegium. This charter's content is compendious and precisely expresses the noble intention of its founder[ MNL - Acta Jesuitica. fasc. 14, num. 3].Emperor Matthew II also confirmed the founding charter of the collegium. Priest Alexander Dobokay was appointed the first rector [Krapka - Mikula, 1990, s. 50]. The school began its activities in the school year $1614-$ 1615. Priest Leonard Klasovics became its first prefect and led the upper grammar class. George Mojzes, the lower one another master. A year later, the humanities class was added, and at that time, priest Stephen Pongrács was the prefect. The school's development and level grew so much that in 1619, there was already a complete secondary school in Homonna, which also had a rhetoric class. At that time, priest George Mojzes was the prefect of the school, and six masters helped him with his teaching [Lukács, 1982, s. 222]. 
According to the instructions of its general superior, the Homonna Secondary Grammar School followed the rules of the Ratio studiorum. Experienced professors paid attention to the comprehensive education of their students. The Jesuit grammar school was actually a sixyear secondary school. The language of instruction was Latin. Among the professors, there were also some Slovaks who had a good influence on Slovak students. Theatre plays enriched the study (in Latin), public rehearsals with awards and academies [Stolárik, 1998, s. 24].

This grammar school was attended mainly by students from aristocratic families from Hungary, but also from Transylvania, Dalmatia, Croatia, and Székely Land [Stolárik, 1998, s. 26-27]. Its high level is also evidenced by the fact that there were many protestant young boys among the catholic students. The chronicler also expressed his appreciation for the grammar school when he wrote: «Many nobles, including non-Catholics, they come to see our college, admire our youth, highly praise the way they teach and ask to put their sons in our school. A certain educated man dared to say that there is no better grammar school in the whole of Hungary than ours, which is still in its infancy» [Lacko, 1957, s. 51, 57].

The Jesuits had more than 200 students at their grammar school. Many, because they were far away, got cheaper accommodation and food. The difficulties associated with it were quickly put into order by count George Druget himself, when he ordered the city council how these problems should be specifically addressed [Machala, 1937, s. 42]. In 1619, the grammar school already had 27 professors, six of whom were already masters. It was a time for the collegium's most prolific work [ARSI, Wienna, fol. $210 \mathrm{r}-211$ v.]. In 1619, an uprising by Gabriel Bethlen broke out. Before his attack, George III Druget escaped to Poland to his castle in the village of Laszki near Przemyśl [Székely, 1977, old. 8]. The Jesuits also left Homonna. Father A. Dobokay reported it to the General Superior in Rome. He stated that on September 2, 1619, fourteen Jesuits ran away from Poland's rebels at midnight with him (the rector).
Others, who were missionaries in the surrounding, took refuge in Druget castles. In Poland, the Jesuits worked in various collegiums and residences of their Community [Stolárik, 1995, s. 33].

From 1619, the activities of the Homonna grammar school as well as the Jesuit pastoral care, were interrupted. The Jesuits did not return until 1629 or 1630 . The historical time between these years remains empty for us [Mészáros, 1861, old. 86]. After they arrived in Homonna, the Jesuits began to prepare for the restoration of the grammar school. In 1632, proper teaching began. Michal Beško, later Gregor Forró and Tamás Jászberényi, became rectors.

John IX Druget, the son of George III, took his father's words to take care of the monks seriously. In 1634, he increased the income of the Jesuits. To 1700 gold coins, he added another 500 gold coins. At the same time, he gave them the villages of Peticse (Ptičie) and Modra as reserves. However, the peaceful activity of the monks did not last long. In 1643, the uprising of George Rákóczi broke out, and John IX Druget escaped to Uzhhorod, where he was safe. The Jesuits did the same and followed the Count to Uzhhorod.

When George Rákóci and his soldiers got to Homonna, having been full of anger, he destroyed the whole town and the castles of Jeszeno" (Jasenov) and Barkó (Brekov) [Székely, 1977, old. 10]. Some of the Jesuits returned to Homonna after December 1, 1645, but they did not restore the collegium. They focused only on pastoral work in and around the city [Stolárik, 1995, s. 34].

Jesuit John IX Druget left in Uzhhorod, where they were safe. They set up a collegium there. Imre Lósi [Rupp, 1876, old. 402-404], a bishop of Eger, had proposed the transfer of the collegium to Uzhhorod to John IX Druget even earlier. The Uzhhorod Collegium began its activities in 1636 . The charter for this college was issued on July 31,1640 . Nevertheless, the official transfer of the collegium from Homonna was made by countess Anna Druget née Jakussich, only on October 8, 1648, which was to inform each visitor about that grammar school:

\title{
Ezen épületben elhelyezett Királyi katholikus fögymnasium alapíttatott: Homonnán Drugeth Homonnai Györgya 1613-ban. Ungvárra áthozta Drugeth Homonnay János gróf 1640-ben [Székely, 1977, c. 10].
}

\begin{abstract}
The royal Catholic grammar school was located in this building, founded in Homonna by George Druget of Homonna in 1613. It was moved to Uzhhorod by John Druget of Homonna in 1640.
\end{abstract}

The Jesuits worked successfully in the grammar school and pastoral care until the abolition of the order in 1773 [Dongó, 1909, old. 30-32]. The work of the Jesuits was not limited only to pedagogical activities. However, to a large extent, they were involved in pastoral care not only in the city itself but in its surroundings.

It should be mentioned that the Jesuits founded the Marian Congregation in 1639 [Karácsonyi, 1915, old. 219]. Its establishment contributed to the deepening of spiritual life and increased respect for the Virgin Mary. Pastoral work in that direction had brought their fruit because historians state that at that time, the great forgiveness in Homonna, which was far from a large number of pilgrims, is beginning to be mentioned.

Some, especially Protestant authors, claim that the recatholicization efforts of count George III Druget were just a political move by which he pursued only his benefit [SEE e.g. the work - Réz, 1899].

Upon closer examination of the historical evidence, we have concluded that his conversion and subsequent steps to the re-Catholicization of his estate were sincere. That is evidenced, among other things, by his next initiative - to bring the Ruthenians who were not united with Rome (Orthodox) into the Catholic Church. The 
Jesuits, who also met with Orthodox believers in their missionary work, helped him a lot in this work [Herman, 1973, old. 271-272].

The Brest Union of 1596 was an example of the realization of this idea. It united the Catholic Church with the Orthodox Ukrainians and Belarusians living in the then Polish state's Union. This action was held in Homonna in September 1613. At the invitation of count George III, the Greek Catholic Bishop of Przemyśl, Atanáz Krupecký (1610 - 1652), came from Poland. About this activity of George III informed the Roman Catholic bishop Stanislav Sieciński in Przemyśl on November 25, 1613, and the Vatican: «The Hungarian nobleman George of Homonna, who returned to the Catholic Church, being encouraged by the zeal of the Catholic faith and the efforts to spread the Union among his people, the Greek rite in their districts, addressed me by letter to send the same Krupecky' to strengthen the Union among his lieges. I had done so a few days earlier» [Gajdoš - Konečný - Mušinka, 1999, d. 12].

Important talks followed, then the bishop's sermon, being assisted by two Basilian fathers. For the Orthodox clergy, this unification meant a higher degree of their status because they would not renounce any of their customs and traditions but would only recognize the Pope of Rome as the head of the Church [Bujňák, 1971, s. 221]. Moreover, the count promised them social equality with the Catholic clergy and the youth's access to the newly formed collegium, etc. In this case, it was of great importance for Orthodox clergy to gain the social status that Catholic priests had because the vast majority of Orthodox pastors were of serf origin and remained serves even after their ordination. They had to pay feudal fees and also go to work in the fields. [Lacko, 1965, s. 99].

When the Homonna estate's Orthodox pastors received these promises, the number of fifty of them voted in favor of unification. The date of that ceremonial act was set for the Pentecost in 1614, and it was to take place at a pilgrimage site in Laborczrévi (Krásný Brod) near Mezőlaborc (Medzilaborce). However, a good idea did not come into existence because the Union's enemies attacked the assembled and Bishop Krupecký himself. Only the soldiers of George III Druget were rescued [Haraksim, 1991, s. 12-13].

Despite the first failure, further attempts for unification were made. The idea of George III Druget was continued by his son John IX. The preparation intensified, especially before 1645. John IX, however, failed to carry out the father's plan. Only John's wife, Catherine, née Jakussich, managed to realize the original intention happily. She was the sister of the bishop of Eger, George Jakushich. In addition to the Jesuit searches, the Basilians, especially Peter Partenius Petrovics and Gabriel Kosovický, continued with that idea. After many difficulties, based on the invitation of the bishop of Eger, George Jakussich, 63 Orthodox parish priests came to Uzhhorod Castle on April 24, 1646, to unite with the Catholic Church. That event was attended by clergymen not only from Uzhhorod, but also Zemplén, Sáros (Šariš), and Szepes (Spiš) counties. They were returning from Uzhhorod as Catholic clergy of the Greek rite: [Vystrčil, 1992, s. 22]. "However, our unification itself took place in the year of salvation in 1646, on April 24, when Ferdinand III was the Roman emperor, in the Roman Catholic castle church in Uzhhorod, on the estate of the brightest count, George of Humenné» [Lacko, 1965, s. 99]. The document regarding that important act was not made until January 15, 1652.

As mentioned above, Valentine I longed to become a prince of Transylvania. Stephen Bocskay also supported him in this effort when he recommended him to the people of Transylvania in his will. Sigismund Rákóczi, who was the father-in-law of Valentine I. Druget [Hóman - Székfü, 1939, old. 52]. Sigismund was finally elected a prince. However, probably under his neighbor's pressure, the Eger pasha, Sigismund, finally gave up the principality in 1608 for good severance pay. The young Transylvanian Gabriel Bátori began to apply for the principality. In this situation, Valentine I did nothing, and Gabriel Bátori was elected a prince. The new prince did not live long because the Pasha arranged for Bátori's envoy, Ondrej Géci, to become the captain of the bastards and capture and killed the prince himself. While this uprising was taking place, General Sigismund Forgács, together with George III, drew to Transylvania in 1613 Druget to make Druget a prince. However, they encountered the Turks and had to leave. George III Druget, after his wife Catherine, was related to the Bátori family, and therefore, he was to have a particular share in the principality. Gabriel Bethlen also began to make his intrigues, and with his diplomacy, he got the sultan to place him in the principality. The sultan gave him a Turkish leader with an army, and Bethlen occupied Transylvania [Jurovský, 1976, d. 16].

At the imperial meeting in Linz in 1614, it was concluded that it was impossible to stand up against the Turks and also against Gabriel Bethlen. George III Druget was left alone in this situation. In January 1615, several members of Hungary's catholic party met in Deregnyő (Drahňov, Michalovce district), where they consulted together on how to remove Gabriel Bethlen, who had sold himself to the Turks and to replace him with George III Druget. Druget was also inclined to the clergy, who received a promise from him that if he succeeded in taking the prince's chair, he would see that the catholic faith spread again in Transylvania. George III, however, had significant opposition in the protestant nobility, and Zemplén county itself was against it. The states of Upper Hungary also met in Kassa (Košice) and assessed the whole situation as unfavorable by George III. For the time being, the fight against Bethlen ceased. In 1616 (March 19), Druget received a letter from the papal secretary encouraging him in a recatholicization plan: «May God establish relations in the way you hope will be in the interest of the freedom and growth of the Catholic faith». This letter encouraged George III to further attempts to defeat Gabriel Bethlen, and this time his county did not want to help him. She even fought against him and destroyed some of his property. George's initiatives, as well as the open struggle of the protestants, much exhausted his treasury [Réz, 1899, old. 92].

George III was so fascinated by the idea that he recruited bastards and recruited the Buda pasha Ali Kadzade for help, who liked to make Gabriel Bethlen uncomfortable. To win over the Turks, Druget promised 
them the Hungarian cities of Lippa and Jenő if he became a prince. In the case of these places, it was a matter of their return. However, Bethlen overtook him because he managed to expel the Hungarian garrison from these places and handed over the Turks' towns in 1616. Palatine George Thurzó tried to eliminate this whole situation by the conventions in Nagyszombat (Trnava) in 1615 and 1617 [Hóman - Székfü, 1939, old. 69].

The Hungarian Assembly was convened in Pressburg (Bratislava) on March 4, 1618, which did not end according to the protestants' wishes. Therefore, dissatisfied protestants turned for help to the Transylvanian prince Gabriel Bethlen, a staunch supporter of Protestantism in Hungary. The protestant historian described the situation as follows: «Not knowing where to turn against the great and many monarchs, led by God, they found the ruler of Transylvania through envoys and letters, so that His Majesty may see the setting danger and regret the ecclesiastical communities and the nation of Hungary and come to his aid against persecutor» [Réz, 1899, old. 94-95]. Gabriel Bethlen took advantage of this situation. Because he gained part of the Hungarian nobility and the Turks' support, in 1619 declared a fight against king Ferdinand II. He invaded eastern Slovakia, occupied Kassa (Košice), and declared himself the head of Hungary. After this victory, he managed to conquer Nagyszombat (Trnava), Érsekújvár (Nové Zámky), and briefly Pressburg (Bratislava). Then he approached Vienna [Ďrica, 1996, s. 53].

However, Gabriel Bethlen could not forgive Druget for his ambitions on the princely throne. Druget also got into trouble with the Zemplén peasants and evangelicals. Gabriel Bethlen had the opportunity on August 26, 1619, and set out on a major military campaign, saying, «For the religious freedom of the protestants in Hungary and Bohemia». Gabriel Bethlen had generous support from the Turks because he was their great ally. His letter, sent by the Turks to Hungary via their envoys in 1620, states, among other things: "great praise. May every act in the work of Gabriel Bethlen, the ruler of Hungarians and Transylvania, be happy. May the great God bless your happy work to you, dear Hungarian and merciful Christian nobles, and to all orders. May this letter serve your dignity as our appreciation, so that you may now choose a king, which would necessarily be required. Choose him freely, according to the norms of the law, so that he may be just to you and that he may behave in good faith towards Our clear Port and live in peace with Us. To live honestly with Hungary under his own rule... Given in Our hometown of Constantinople, on the 26th in the month of directing in 1620 of our Prophet Muhammad» [Szirmay, Notitia historica, old. 149].

In January 1620, Gabriel Bethlen convened an assembly in Pressburg (Bratislava), where they approved his confederation with the Czech and Austrian states and also declared religious freedom. Subsequently, in August, at an assembly in Besztercebánya (Banská Bystrica), he was elected by the protestant nobility as king of Hungary. At the same time, the affairs of the Zemplén people were also resolved there. Gabriel Bethlen declared, among other things: «That he was always inclined to make peace. The armistice was broken by the emperor, because he called the Kozaks from Poland under the leadership of George Druget of Humenné, who ravaged the kingdom on all sides». In article no. 26, it was decided who was to receive the property of George Druget, who died before his confiscation [Szirmay, Notitia historica, old. 149]. At the same time, they expelled the Jesuits from the country and confiscated their property. This assembly also decided that Cardinal Peter Pázmanyto be expelled from Hungary and that his property would be confiscated. Due to the defeat of the Czech estates (protestants) in the battle of Bílá Hora near Prague (November 8, 1620), he began to lose the support of the Slovak and Hungarian nobility [Durica, 1996, s. 53].

Even in Košice, Gabriel Bethlen ordered his George I Rakóci to punish George III with a special expedition. George III Druget could not be persuaded by force to oppose king Ferdinand II. Bethlen's soldiers took revenge on him by plundering his castles and property. Since count Druget could not oppose them, he went with his wife Catherine to Poland to his estate Laski and hired 8,000 cossacks and attacked George I Rákóci, who, assuming that Druget was already definitively defeated, returned triumphantly to Kassa (Košice) and administered Upper Hungary in Bethlen's name [Kopčan, 1986, s. 115]. This battle was described by the German writer Ketteler as follows: «There he gathered an army and returned. In contrast, he came out on November 23 at Homonna Rakóczi, whom Bethlen left with part of the army to protect Košice. The two met vigorously in battle, but the lord of Homonna was banished. However, he did not lose his mind at all and returned soon, strengthened after the arrival of reinforcements from Rodelcans and from count Altemisius. He embarked on a fierce battle again, which lasted for two days. Then he retreated toa certain place and the Poles simulated an escape. When the Hungarians and Transylvanians broke their advice, as if they had already achieved victory and began to look more for prey, they returned and easily dispersed the loose bullets, unable to fight. They killed almost all infantry bastards and 1,500 nobles. The other riders and Duke Rákóczi himself fled. There was a great fear in Kassa (Košice) and Eperjes (Prešov). Betlén himself was also shaken by the defeat brought about by the message, and fearing for his property and his principality, he withdrew from Vienna and sent Ferenc Rhédey with part of the army to tame the lord of Homonna» [Suchý, 1974, old. 188]. When Rákóczi was expelled, George III Druget, together with the Poles and the hired cossacks, began to plunder the wealthy estates of Rákóczi and Bethlen. From the town of Újhely to Szerencs, he plundered everything by driving away small and large cattle and the population. He returned to Poland with enormous and rich prey [Szirmay, Notitia historica, c. 149]. Bethlen's dream on George III he was punished for confiscating his property, but the report caught him dead [Jurovský, 1976, s. 17].

The military position of George III Druget was of great political importance. He managed to save Vienna and Emperor Ferdinand II by forcing Gabriel Bethlen to renounce the orbit of Vienna and return. In the meantime, the emperor received military aid, and insurgents, despite 
Turkish aid, soon had to negotiate with him, which led to the signing of peace in Mikulov on January 7, 1622. Bethlen thus lost the title of king of Hungary and had to return the territories he had wrongly appropriated. However, for the rest of his life, he retained jurisdiction over Transylvania and over the seventh north-eastern capitals of Hungary. He also received the title of Reich Prince. An exception in the jurisdiction over the chairs was, however, the Zemplén and Ung counties, which remained in the possession of the counts of the Druget family [Lacko, 1957, s. 49-50].

Gabriel Bethlen's troops imprisoned and then cruelly tortured three Catholic priests during the occupation of the city of Košice - the Esztergom canon Marek Križin, originally from Croatia, and two Jesuit searchers, Stephen Pongrács from Transylvania, and Melchior Grodziecký from Silesia. They are known as the martyrs of Kassa (Košice) [Bagin, 1989, s. 445-447].

We also learn about George III that for the town of Homonna, he demanded on March 14, 1615, from king Matthew II. (1608 - 1619) permission to collect tolls. In this charter, the king appreciates that «he made little effort for the general safety of the wanderers and for their benefit he built bridges ...We give him, from our special favor, the right to build a toll booth under these conditions». In the next part, the king justifies the justification and importance of Grodecki this toll booth: "Near the town of Homonna, due to the many dangers on the roads for passengers (and traders), he took care of their safety, had bridges built in the necessary places and to reimburse my expenses» [ŠA PrešovDrugeth - Humenné, inv. č. 81, sign. I - 81].

At the assembly in 1618, Article 25 also ordered a revision of the dispute between countess Catherine Druget, the wife of George III Druget, concerning the castle of Ecsed, according to an exceptional right granted to the palatine himself [Szirmay, Notitia historica, c. 143]. Based on the Peace of Mikulov, the property was returned to its owners. In the case of George III an order was issued: "The heirs of the poor count George of Humenné, Mr. Sovereign, after taking over the country, will immediately make their castles and property available to the surviving count's widow as a natural and lawful tutor and orphan» [Réz, 1899, old. 96]. The Kassa (Košice) Chamber was to ensure that this property was well managed and later when the children grow up also divided. Stephen Gombos was entrusted with the property management, and they were also assigned a salary, rights, obligations, etc.

George III Druget died in Poland (Laski) on July 21, 1620 , at the age of 37 . The cause of death was poisoning. On his deathbed, he begged his only nine-year-old son, John IX, to take care of the Jesuits. His body remains were transported by the Jesuits to Nagyszombat (Trnava) and buried in the church of St. Nicholas [Ferkov, 2014, c. 108-109]. George III. together with the palatine George Thurzó and his brother-in-law Peter Zichy, prepared a plan to save the property of Elisabeth Bátori (Lady of Cachtice), who was the mother of Catherine, George's wife. His wife inherited part of this property, and at the same time, he saved Elizabeth (his mother-in-law) from the death penalty [Slovenský biografický slovník, 1986, s. 506-507].

Catherine Druget, born Nádasdy, wife of George III, was buried in the Church of St. Nicholas as her husband [Jurovský, 1976, s. 18].

In evaluating the life of George III, we can say that his involvement in political life has not brought about any significant changes. However, he distinguished himself extensively in the religious field. Its conversion to the Catholic faith, the vocation of the Jesuits to Homonna, and the subsequent establishment of the Jesuit college (Collegium Homonense) brought significant results in the spiritual, cultural, and social spheres. George III had two daughters and one son with his wife Catherine Nádasdy (daughters of Francis and Elisabeth Bátori). Elisabeth's daughter married baron Ladislav Révay († 1667) [Szirmay, Notitia topographica, c. 78], the second daughter Maria became the wife of George Sécsi $(\dagger$ 1625). The only son John IX became the successor of the family [Doby, 1897, old. 74-76].

After the death of George III, on June 26, 1622, a new mayor of Zemplén, Melchior Alaghy, was appointed to replace him in the county [MNL - A57, MKL, LR, zv. 7, s. 155].

\section{References}

\section{Sources}

Archivum Secr. Vaticanum, Armarium 45, vol. 1. Fol. 248v. et alia copia etiam in vol. 1. A., fol. 451r.

Osterreichische Nationalbibliothek in Wien. ARSI Austria:

fol. $210 \mathrm{r}-211 \mathrm{v}$.

vol. 133 , fol. 189 .

Magyar Nemzeti Levéltár, (MNL):

A 57, MKL, LR, zv. 14., s. 308.

A57, MKL, LR, zv. 5, s. 580-582.

A57, MKL, LR, zv. 7, cs. 155.

Acta Jesuitica. Collegium Ungvariense, fasc. 14, num. 3.

Acta Jesuitica. Collegium Ungvariense, fasc. 14, num. 6

Slovenská národná knižnica Martin, Literárny archív, Rukopisy historických knižníc na Slovensku, Acta Jesuitarum in Hungaria ab anno 1599 usque 1647 (sign. RHKS 1425a).

Štátny archív v Prešove (ŠA Prešov). Drugeth - Humenné:

inv. č. 80a, sign. I - 80a. 
inv. č. 81 , sign. I -81 .

inv. c. 503. 1. Fasc. 4. №. 10.

\title{
Literature
}

Bagin, A., 1989.De beatis martyribus Cassoviensibus I., Duchovný pastier, č. 10, s. 445-447.

Borbély, Z., 2015. A Homonnai Drugethek Felsö-Magyarországon a 17. század első évtizedeiben, Eger, 255 old.

Borbély, Z., 2017. Homonnai Drugeth (III.) György hütlenségi pere (1600-1603), SZÁZADOK. A Magyar Történelmi Társulat folyóirata Az alapitás éve 1867, 2017, 273-310 old.

Bujňák, J., 1971. Pokusy o úniu v mukačevskej diecéze, Duchovný pastier, č. 5, máj 1971, s. 221-223.

Doby, A., 1897. A gróf Drugeth-család leszármazása, Adalékok Zemplén vármegye történetéhez, Sátoralja-Újhely, zv. II., č. III. - IV., 74-76 old.

Dongó, G. Gy., 1909. A Homonnai Drugeth - kollégium jezsuiták vezetése alatt. Adalékok Zemplén vármegye történetéhez, Sátoralja-Újhely, 30-32 old.

Durica, M., 1996. Dejiny Slovenska a Slovákov, Bratislava, 288 s.

Ferkov, O. V., 2014. The sources of school education in Zakarpatta, Tisiačolitia-Millennia 1, s. 104-1116.

Franzen, A., 1992. Malé cirkevní dějiny, Praha, 333 s.

Gajdoš, M. - Konečný, C. - Mušinka, M., 1999. Rusini / ukrajinci v zrkadle polstoročia, Prešov-Užhorod, 157 s.

Haraksim, L., 1991. Užhorodská únia a Slovensko, Historická revue, č. 7, roč. II, s. 12-14.

Herman, E., 1973. A katolikus egyház története Magyarországon 1914-ig., München, 271-272 old.

Hóman, B. - Székfü, Gy., 1939. Magyar történet IV, Budapest, 52. old.

Jurovský, J., 1976. Drugethovci, Kalinov, s. 13.

Karácsonyi, J., 1915. Magyarország egyháztörténete föbb vonásaiban 970-töl 1900-ig., Nagy-Várad, 408 old.

Kopčan,V., 1986. Turecké nebezpečenstvo a Slovensko, Bratislava, $222 \mathrm{~s}$.

Krapka, E. - Mikula, V., 1990. Dejiny Spoločnosti Ježišovej na Slovensku, Dobrá kniha, Cambridge, $526 \mathrm{~s}$.

Lacko, M., 1957. Humenné, politické, kultúrne a náboženské stredisko na východnom Slovensku v XVII. storočí, Most 2,s. $51,57$.

Lacko, M., 1959. Užhorodská únia, Most, č. 5, s. 112-113.

Lacko, M., 1965. Unio Užhorodensis ruthenorum carpaticorum cum Ecclesia catholica, Roma, p. 91-113.

Lenčiš, Š., 2003. Šlachtický rod Drugetovcov z Humenného, Humenné, 183 s.

Lukács, L., 1982. Catalogi personarum et officiorum provinciae Austriae S.I. Vol. 2. (1601 - 1640), Romae, 804 p.

Machala, J., 1937. Die Jasuiten in der Ostslovakei zur Zeit der Genenreformation, Innsbruck, p. 42.

Mazúr, J., 1973. Pramene k dejinám Slovenska vo Viedenskom štátnom archíve., Slovenská archivistika, č. 2, roč. VIII., s. 207.

Mészáros, K., 1861. Ungvár története a legrégibb időktöl máig, Pesten, 86 old.

Réz, L., 1899. A Drugethek és Homonna reformátiója. Sátoraljaújhely, 162 old.

Rupp, J., 1876. Magyarország helyrajzi története III., Budapest, 402-404 old.

Slovenský biografický slovník I., 1986.Martin,s. 506-507.

Somogyi, Z.,1902. Magyarország föispánjainak története 1000-1903, Budapest, 256 old.

Stolárik, S., 1995. Humenské kolégium a traja košicki mučeníci, Humenné $98 \mathrm{~s}$. s. 24.

Stolárik, S., 1998. Tristoosemdesiate výročie Humenského kolégia, Humenné - zborník príspevkov k histórii mesta, Humenné,

Suchý, M., 1974. Dejiny Levoče I., Košice, s. 188.

Székely, A., 1977. Jezuiti v Humennom, Humenné, Rkp., s. 10.

Szirmay, A., 1803. Notitia topographica, politica inclyti comitatus Zempléniensi c. Budae, 240 p.

Szirmay, A.,1804. Notitia historica comitatus Zempléniensi c. Budae, 105- 106 p.

Takács, C.,1900. A Homonnai Druget-család romlása. Adalékok Zemplén vármegye történetéhez, Sátoralja-Újhely, zv. 6, č. V., $158-160$ old.

Vystrčil, J.,1992. Křest'anský východ, Olomouc,139 s.

\section{SUMMARY}

\section{ОСОБИСТІСТЬ ДЬОРДЯ ІІІ ДРУГЕТА ТА ЙОГО ІСТОРИЧНА ДІЯЛЬНІСТЬ У КОМІТАТАХ ЗЕМПЛІН ТА УНГ НА РУБЕЖI XVI - XVII СТ.}

\author{
prof. ThDr. PhDr. Штефан Ленчиш, PhD \\ професор історії церкви, директор Інституту історії церкви, \\ Католицький університет в Ружомберку, Кошиці, Словаччина
}

Серед багатьох аристократів важливу історичну роль має родина Другетів із Гуменного, які є одними з найвідоміших аристократичних сімей в Угорщиин. Більще ніж три з половиною століття діяльності знаменитої родини Другетів в Угорщині відзначається багатьма історичними подіями. Відомий історик Матей Бел на початку ХVIII століття досліджував історію маєтків і господарство, щчо лежали в околицях Гуменного. Цей старовинний осідок досліджуваної родини $i$ замок були не лише прекрасно оздоблені $i$ впорядковані, але і мали обширні території. Бажання Матея Бела вивчити історію аристократів так $і$ не було здійснено вповні. Та й сама родина Другетів, ні їх нащадки не були защікавлені розкривати свою давню $i$ багату сімейну історію для майбутніх поколінь. Через життя Дьордя III Другета ми хочемо вказати, принаймні в невеликій мірі, на характер иієї важливої сім'ї. Цього року ми вщановуємо 400 років з дня смерті графа Дьордя III, який на рубежі XVI - XVII століть зробив значний внесок в історію комітатів Земплін та 
Унг. Його життя було здебільшого пов'язане з містечками Гуменне та Ужгород. Дьордь ІІІ належав до одного з найважливіших представників иієї знаменитої родини в Угорщині в політичній, економічній, культурній та релігійній сферах. Вивчення архівних джерел приносить нові знання. Цією роботою ми хочемо хоча б частково заповнити прогалину в історичних дослідженнях. Ми хочемо конкретизувати історичні приклади найважливіших подій пов'язаних з Дьордьом ІІІ Другетом і дотичних тем: місіонерської діяльності єзуїтів, створення гімназї в Гуменному та його перенесення в Ужгород та власне Ужгородську унію. У той же час, діяльність у ичих сферах представляє їх взаємний вплив, співпрацюю, досягнення, а також труднощі. Ми хочемо вказати на їх важливе становище у вирішальні історичні моменти. Дане дослідження також прагне спростувати часто однобічне ставлення сучасних людей до знатних сімей, які через вплив недавнього комуністичного минулого досі сприймаються як експлуататори та могутні дворяни.

Ключові слова: граф, гімназія, Другет, замок, комітат, маєтки. 